\title{
SZCZEgółoWe ObOWIĄZKI KANONICZNE PROBOSZCZA W ZAKRESIE NAUCZANIA, UŚWIĘCANIA I PASTERZOWANIA
}

\section{Wstęp}

Urząd proboszcza jest ściśle związany z parafią. W prawie Kościoła łacińskiego „parafia jest to określona wspólnota wiernych w Kościele partykularnym, ustanowiona na sposób stały, w której sprawowanie troski duszpasterskiej pod władzą biskupa diecezjalnego jest powierzone proboszczowi jako jej własnemu pasterzowi" (KPK kan. 515 § 1). Takie rozumienie parafii jest wynikiem wpływu eklezjologii Soboru Watykańskiego II, według której parafia jest rozumiana jako wspólnota wiernych i jakby komórka diecezji ${ }^{1}$. Na jej czele stoi proboszcz ${ }^{2}$, zastępujący biskupa. Z proboszczem zaś współpracują wikariusze, jako jego pomocnicy ${ }^{3}$. Urząd proboszcza stanowi istotny element parafii (kan. 515).

* Ks. prof. KUL, dr hab.; Katolicki Uniwersytet Lubelski Jana Pawła II.

1 „Parafia dostarcza naocznego przykładu apostolstwa wspólnotowego, gromadząc $\mathrm{w}$ jedno wszelkie występujące $\mathrm{w}$ jej obrębie różnorakie właściwości ludzkie i wszczepiając je w powszechność Kościoła. (...) Niech będą zawsze uwrażliwieni na sprawy diecezji, której parafia jest jakby komórka, gotowi zawsze na wezwanie swego pasterza zaangażować własne siły w przedsięwzięcia diecezjalne. (AA 10). J. Krukowski, Parafie, proboszczowie i wikariusze parafialni, [w:] J. Dyduch, W. Góralski, E. Górecki, J. Krukowski, M. Sitarz, Komentarz do Kodeksu Prawa Kanonicznego, t. II/1, Poznań 2005, s. 410.

2 Łacińskie brzmienie rzeczownika parochus stanowi zlatynizowaną formę greckiego rzeczownika Táoo ðos (siedzący obok na wozie, dostawca, dostarczyciel artykułów pierwszej potrzeby), O. Jurewicz, Stownik grecko-polski, Warszawa 2001, s. 168.

3 „Szczególnymi współpracownikami biskupa są proboszczowie, którym jako właściwym pasterzom, pod jego zwierzchnictwem, powierzana jest troska o dusze w określonej części diecezji. W okazywaniu tej troski proboszczowie wraz ze swoimi współpracownikami niech tak wypełniają posłannictwo nauczania, uświęcania i kierowania, aby wierni oraz wspólnoty parafialne czuli się rzeczywistymi członkami tak diecezji, jak i całego Kościoła 
Tak zorganizowana jednostka podziału administracyjnego ma długą historię powstawania. Sam termin parafia pochodzi z języka greckiego, w którym od czasownika $\pi \alpha \varrho o u k \varepsilon ́ \omega$ (mieszkać wzdłuż, żyć w pobliżu, być sąsiadem, przebywać wśród kogoś, mieszkać jako obcy) powstał rzeczownik $\pi \alpha \varrho o \iota k i ́ \alpha$ (pobyt w obcym kraju, przebywanie na obczyźnie; a także: mieszkanie $\mathrm{w}$ sąsiedztwie, w pobliżu $\mathrm{u}^{4}$. W takim znaczeniu ten czasownik występuje w Dz 13, 17. W języku łacińskim używano tego słowa w zlatynizowanym brzmieniu parochia lub paroecia -w znaczeniu parafia ${ }^{5}$. Określenia paroecia używano w IV w. na określenie diecezji ${ }^{6}$, a w VI w. na określenie diecezji wiejskich i mniejszych ośrodków duszpasterskich. Od XI w. diecezje dzielono na parafie, na których czele stali proboszczowie ${ }^{7}$. Podział taki potwierdzono na Soborze Trydenckim (ses. XIV, c. 9, de ref.; ses. XXIV, c. 13, de ref.) $)^{8}$. Od tego też czasu przyjęło się na sposób trwały określenie parochus ${ }^{9} \mathrm{w}$ stosunku do kapłana stojącego na czele parafii.

\section{Proboszcz}

Istnieje legalna definicja proboszcza, którą ustawodawca zawarł w kan. 519. „Proboszcz jest własnym pasterzem powierzonej mu parafii, sprawującym troskę pasterską względem powierzonej mu wspólnoty pod zwierzchnictwem biskupa diecezjalnego, do współuczestnictwa z którym w posłudze Chrystusa został powołany, ażeby dla tejże wspólnoty wykonywał zadania nauczania, uświęcania i zarządzania, we współpracy także z innymi prezbiterami i diakonami oraz udzielającymi pomocy wiernymi świeckimi, zgodnie z normami prawa”. Ważnym jest określenie „pastor proprius" - własny pasterz. Podobny zapis ma miejsce w kan. $515 \S 2$ oraz $516 \S 2$. „Własny pasterz" oznacza, że uprawnienia i obowiązki „otrzymuje za pośrednictwem urzędu powierzonego mu przez biskupa. Wła-

powszechnego". (CD 30), J. Dyduch, W. Góralski, E. Górecki, J. Krukowski, M. Sitarz, Komentarz..., s. 410.

4 Z. Węclewski, Słownik grecko-polski, Warszawa 1929, s. 517; O. Jurewicz, Słownik grecko-polski, t. II, Warszawa 2001, s. 167.

${ }^{5}$ A. Jougan, Stownik kościelny łacińsko-polski, Warszawa 1992, s. 481.

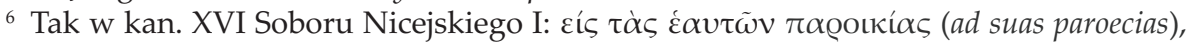
A. Baron, H. Pietras, Dokumenty Soborów Powszechnych, t. I, Kraków 2002, s. 40-41.

7 J. Dyduch, W. Góralski, E. Górecki, J. Krukowski, M. Sitarz, Komentarz..., s. 410.

8 Tamże.

9 S. J. Lederhilger, Der Pfarrer, [w:] S. Haering, W. Rees, H. Schmitz, Handbuch des katholischen Kirchenrechts, wyd. 3, Verlag Friedrich Pustet, Regensburg 2015, s. 681. 
dza, jaka przysługuje proboszczowi, jest zwyczajna i w swoim zakresie własna, czyli wykonuje on ją w imieniu własnym. Proboszcz nie jest więc wikariuszem biskupa, natomiast wikariusze parafialni są wikariuszami proboszcza"10. Proboszcz posiada własne uprawnienia, ale władzy rządzenia nie sprawuje ${ }^{11}$.

Proboszcz wykonuje swój urząd nie w zastępstwie biskupa lecz samodzielnie, z władzą zwyczajną i osobistą odpowiedzialnością, chociaż ze względu na uczestnictwo (Einbindung) w Kościele partykularnym i hierarchiczne podporządkowanie biskupowi diecezjalnemu cieszy się on tylko ", względną autonomią"12. Proboszcz swoje zadania spełnia pod władzą biskupa w sensie eklezjologicznym i prawnym. W sensie eklezjologicznym - w takim znaczeniu, że uczestniczy w urzędowym kapłaństwie Chrystusa pod przewodnictwem biskupa diecezjalnego. Wypełnia zadania nauczania, uświęcania i zarządzania we wspólnocie Kościoła partykularnego (LG 28b, CD 30). „W sensie prawnym proboszcz otrzymuje urząd pasterza parafii od biskupa w formie nominacji. Poprzez nominacje (kan. 532) biskup diecezjalny powierza prezbiterowi parafię jako cząstkę trzody Pańskiej, której nadal pozostaje głównym pasterzem"13.

\section{Powierzenie urzędu proboszcza (provisio canonica)}

Powierzenie urzędu proboszcza regulowane było prawem papieskim i synodalnym. Kandydat musiał mieć ukończone dwadzieścia pięć lat i miał być ",człowiekiem godnym polecenia ze względu na swoją wiedzę i obyczaje"14. Jeżeli ten, kto stał się zarządcą kościoła parafialnego ${ }^{15}$, nie

${ }^{10}$ J. Dyduch, W. Góralski, E. Górecki, J. Krukowski, M. Sitarz, Komentarz..., s. 417-418.

11 J. Krukowski, Konkretne akty administracyjne, [w:] J. Krukowski, R. Sobański, Komentarz do Kodeksu Prawa Kanonicznego, t. I Księga I Normy ogólne, Poznań 2003, s. 216, taką własną władzę rządzenia sprawują: papież kan. 331 § 1, kolegium biskupów kan. 336, biskup diecezjalny kan. 381 § 1, także, ale z ustanowienia kościelnego metropolici kan. 432 $\S 1$, prałaci i opaci terytorialni kan. 370, administrator diecezji kan. 427 § 1, biskup polowy SMC II § 1, prałat personalny kan. 299.

12 S. J. Lederhilger, Der Pfarrer..., s. 686.

${ }^{13}$ J. Dyduch, W. Góralski, E. Górecki, J. Krukowski, M. Sitarz, Komentarz..., s. 418.

${ }^{14}$ Ten wymóg ze wskazaniem dokumentów kościelnych wykazuje A. Baron, H. Pietras, Dokumenty Soborów Powszechnych, t. II, Kraków 2004, s. 173, przyp. 14. Tak postanowiono na Soborze Laterańskim III (1179) w kan. 3, 3, A. Baron, H. Pietras, tamże, s. 173. Ten sam wymóg potwierdzono na Soborze Lyońskim II (1274), kan. II/13, 1-2; tekst I, 6, 14 in $\mathrm{VI}^{\circ}$, Ae. Friedberg, Corpus Iuris Canonici, Pars II, Graz 1959, kol. 953-954.

${ }^{15}$ Sobór Lyoński II (1274), kan. II/13,2: „in parochiali ecclesia, cuius rector extiterit”. 
miał święceń, musiał w ciągu roku ${ }^{16}$ przyjąć święcenia prezbiteratu i rezydować w kościele parafialnym. Jeżeli nie przyjął święceń, na mocy konstytucji soborowej (ipso iure) był pozbawiony powierzonego sobie kościoła. Od obowiązku rezydencji można było, na pewien czas, jeżeli wymagała tego rozsądna przyczyna, uzyskać od biskupa dyspensę ${ }^{17}$. Co do zasady postanowiono na Soborze Lyońskim II, że nikt nie może powierzyć kościoła parafialnego komuś, kto nie jest prawnie pełnoletni (25 lat) oraz nie jest kapłanem ${ }^{18}$.

Powierzenie urzędu kościelnego, kształtowane prawnie przez wieki, w obowiązującym obecnie prawie, dokonuje się poprzez swobodne nadanie przez kompetentną władzę kościelną (kan. 147). Powierzenie tego urzędu może dokonać się „poprzez przydzielenie przez nią dokonane, jeżeli poprzedzała je prezentacja; poprzez zatwierdzenie lub dopuszczenie, przez nią dokonane, jeżeli poprzedzał je wybór lub postulacja; poprzez zwykły wybór przyjęty przez elekta, jeżeli wybór nie wymaga zatwierdzenia" (kan. 147).

Należy podkreślić, że „urzędu kościelnego nie można ważnie otrzymać bez kanonicznego powierzenia" (kan. 146). Nikt sam nie może ważnie objąć urzędu. W doktrynie wyróżnia się trzy elementy prowizji kanonicznej: 1. wyznaczenie osoby 2. nadanie tytułu 3. objęcie w posiadanie. Odróżnia się objęcie urzędu jako formalny akt, „,którym jego tytulariusz rozpoczyna jego sprawowanie, od zwykłego faktu objęcia urzędu, koniecznego do wykonywania związanych z nim zadan'"19. Ten formalny akt objęcia urzędu nie należy do elementów prowizji kanonicznej wymaganych do jego ważności, ale jego brak uznawany jest (kan. 527 § 3) „za równoznaczny z rezygnacją" ${ }^{20}$.

Interesujący nas urząd proboszcza jest nadawany przez kompetentną władzę kościelną. Zgodnie z brzmieniem kan. 157 - „Jeżeli prawo czegoś innego wyraźnie nie postanawia, do biskupa diecezjalnego należy swobodne powierzanie urzędów kościelnych we własnym Kościele partykularnym". Dotyczy to również urzędu proboszcza, co jest uregulowane w kan. 523 - „Z zachowaniem w mocy przepisu kan. $682 \S 1$, powierzenie urzędu proboszcza przysługuje biskupowi diecezjalnemu i to właśnie

${ }^{16}$ Sobór Lyoński II (1274), kan. II/13, 2: „infra annum”.

17 Tamże.

18 Sobór Lyoński II (1274), kan. II/14: „Nemo deinceps parochialem ecclesiam alicui, non constituto in aetate legitima et sacerdotio, commendare praesumat".

${ }^{19}$ J. Krukowski, R. Sobański, Komentarz..., s. 236.

${ }^{20}$ Tamże. 
przez swobodne nadanie, chyba że komuś przysługuje prawo prezentacji lub wyboru".

Urząd związany z pełnym duszpasterstwem może być powierzony tylko tej osobie, która ma święcenia kapłańskie. Tak rozstrzyga to ustawodawca w kan. 150 - „Urzędu związanego z pełnym duszpasterstwem, do którego wypełnienia wymagane jest wykonywanie władzy święceń kapłańskich, nie można ważnie nadać temu, kto nie otrzymał jeszcze takich święceń". Reguluje to przepis kan. 521 - „§ 1Ażeby ktoś mógł ważnie zostać proboszczem, powinien mieć święcenia prezbiteratu. $\S 2$. Ponadto powinien się odznaczać zdrową nauką i dobrymi obyczajami, gorliwością pasterską i innymi cnotami, jak również mieć kwalifikacje, które wymagane są do kierowania parafia, o którą chodzi, czy to przez prawo powszechne, czy przez prawo partykularne. $\S 3$. Ażeby komuś powierzyć urząd proboszcza, trzeba jego zdatność z pewnością stwierdzić w sposób przez biskupa diecezjalnego określony, także przy pomocy egzaminu".

Urząd proboszcza jest traktowany jako „urząd podstawowy" 21 i wymienia się gow kategorii razem $\mathrm{z}$ urzędem papieskim, metropolity i biskupa diecezjalnego ${ }^{22}$. Wymaga on posiadania władzy święceń i wynikającej z niej władzy przewodzenia ludowi Bożemu ${ }^{23}$. Rozróżnienie pomiędzy „urzędami pełnomocniczymi” (bevollmächtigten Ämtern) i „urzędami bez pełnomocnictwa" (vollmachtsfreien Ämtern) opiera się na władzy płynącej ze święceń i władzy przewodniczenia, które w Kościele są wykonywane w oparciu o potestas sacra ${ }^{24}$.

W literaturze kanonistycznej proponuje się potrzebę wyodrębnienia funkcji bezpośrednio duszpasterskich (nauczanie, uświęcanie, pasterzowanie) i pośrednio duszpasterskich (administracja kościelna, sądownictwo, caritas). Jeżeli z urzędem jest związana bezpośrednia funkcja duszpasterska, to należy zaliczyć go do duszpasterskich. Ma to miejsce również wówczas, gdy obok funkcji duszpasterskiej tytulariusz urzędu wykonuje inne zadania. $Z$ takimi urzędami związane duszpasterstwo jest zawężone funkcyjnie (kanonik penitencjarz, katecheta), personalnie (duszpasterz

${ }^{21}$ W niemieckojęzycznej literaturze kanonistycznej rozróżnia się „Grundamt” i „Hilfsamt" (także Stellvertretungsamt), Ch. Ohly, Das Kirchenamt, [w:] S. Haering, W. Rees, H. Schmitz, Handbuch..., s. 236.

${ }^{22}$ Tamże.

${ }^{23}$ KPK kan. 274 § 1. „Tylko duchowni mogą otrzymać urzędy, do wykonywania których wymaga się władzy święceń albo kościelnej władzy rządzenia".

$\S 2$. Duchowni mają obowiązek - chyba że usprawiedliwia ich prawnie uznana przeszkoda - przyjąć i wiernie wypełnić zadanie powierzone im przez własnego ordynariusza".

${ }^{24}$ Ch. Ohly, Das Kirchenamt..., s. 236. 
akademicki) lub lokalnie (rektor kościoła). Natomiast urząd związany z pełnym duszpasterstwem jest ustanowiony nie dla jednej z funkcji duszpasterskich, ale dla wszystkich łącznie (kan. 386-400; 519; 529; 530; 534) ${ }^{25}$. Pełne duszpasterstwo jest związane z wykonywaniem władzy święceń, które należą do istotnych cech urzędu i dlatego urząd proboszcza jest dostępny dla osób, które w chwili powierzania urzędu są już kapłanami ${ }^{26}$.

Kapłan, któremu ma być powierzony urząd proboszcza powinien „pozostawać we wspólnocie Kościoła i być zdatnym, czyli posiadać przymioty wymagane do tego urzędu prawem powszechnym, partykularnym lub fundacyjnym" (kan. 149 § 1). Takie wymaganie prawodawcy kościelnego związane jest z faktem, że tytulariusz urzędu proboszcza ma wypełniać misję Kościoła a utożsamianie się z Kościołem jest podstawowym wymogiem. Nie wyklucza to krytycznego widzenia spraw Kościoła i rzetelnych, ewangelicznych dążeń do zmian.

Sąd o zdatności kandydata do urzędu, o który chodzi, „,należy do podmiotu nadającego urząd" ${ }^{\prime 27}$. Subiektywny sąd o większej zdatności innego kandydata nie stanowi podstawy „do cofnięcia nadania”"28. Kapłan, który zgodnie z prawem został mianowany na urząd proboszcza i kanonicznie objął urząd, otrzymuje wszystkie uprawnienia i podejmuje obowiązki związane z pełnieniem urzędu.

Prezbiterzy „na mocy sakramentu kapłaństwa, na podobieństwo Chrystusa, Najwyższego i Wiekuistego Kapłana (Hbr 5, 1-10; 7, 24; 9, 11-28), są wyświęcani, aby głosić Ewangelię, być pasterzami wiernych i sprawować kult Boży jako prawdziwi kapłani Nowego Testamentu. Uczestnicząc zaś na swoim stopniu posługi w misji jedynego Pośrednika, Chrystusa (1 Tm 2, 5), głoszą wszystkim słowo Boże (LG28). Jest to pierwsze zadanie z tria munera.

\section{Obowiązki w zakresie nauczania (munus docendi)}

Obowiązek nauczania powierzonej sobie porcji ludu Bożego Kościoła partykularnego, jaką jest parafia, spoczywa na proboszczu. Stanowi to jego własne zadanie. Zgodnie z kan. 757 „Do własnych zadań prezbiterów, którzy są współpracownikami biskupów, należy głoszenie Ewan-

\footnotetext{
${ }^{25}$ J. Krukowski, R. Sobański, Komentarz..., s. 241-242.

26 Tamże, s. 242.

27 Tamże, s. 240.

${ }_{28}$ Tamże.
} 
gelii Bożej. Ten obowiązek spoczywa zwłaszcza na proboszczu oraz innych duszpasterzach, w stosunku do powierzonego im ludu. Jest również rzeczą diakonów uczestniczyć w posłudze słowa, we wspólnocie z biskupem i jego prezbiterium".

Ustawodawca powszechny wzmacnia jeszcze ten obowiązek przepisem prawa w kan. $528 \S 1$ 1.- „Proboszcz jest zobowiązany zatroszczyć się o to, ażeby przebywającym w parafii w sposób pełny było głoszone słowo Boże. Stąd ma starać się o to, by wierni świeccy byli właściwie o prawdach wiary pouczani, zwłaszcza przez głoszenie homilii w niedziele i święta nakazane oraz przez nauczanie katechetyczne".

Ustawodawca wskazuje na przedmiot, środki i sposoby oraz podmioty nauczania. Jako pierwszy i najważniejszy, nakłada ustawodawca na proboszcza obowiązek nauczania. Przedmiotem nauczania ma być „słowo Boże". Należy przez nie rozumieć zespół prawd zawartych w Objawieniu Bożym, czyli Piśmie świętym i Tradycji. Słowo Boże ma być głoszone integralnie. Zgodnie z kan. 760 - „W posłudze słowa, która winna opierać się na Piśmie świętym, Tradycji, liturgii, Nauczycielskim Urzędzie i życiu Kościoła, należy przedstawiać w całości i wiernie tajemnicę Chrystusa". Nauczanie powinno obejmować wszystkie prawdy. Słowo Boże ma być głoszone całkowicie i zgodnie z prawdą ${ }^{29}$ (kan. 747).

W swoim nauczaniu proboszcz nie może przemilczać części doktryny, ani podawać błędnych jej interpretacji. Nauczanie ma obejmować wszystkich „przebywających w parafii”, ma je charakteryzować duch misyjny (CD 30a). Zadaniem proboszcza jest docierać w dzisiejszym sekularyzującym się świecie do wszystkich, także do jeszcze nieochrzczonych, jak również do ochrzczonych, ale nie będących w pełnej jedności Kościołem katolickim ${ }^{30}$.Wśród form nauczania ustawodawca wyszczególnia homilię, nauczanie katechetyczne oraz wychowanie katolickie dzieci i młodzieży.

\section{a) Homilia}

Proboszcz ma głosić homilię „w niedzielę i święta nakazane”. Stanowi to jego obowiązek. Nie może się od tego obowiązku bez poważnej obiektywnej przyczyny uchylać czy przerzucać go na wikariuszy czy diakonów.

${ }^{29}$ „vollständig und wahrheitsgetreu” S. J. Lederhilger, Der Pfarrer..., s. 698.

${ }^{30}$ J. Dyduch, W. Góralski, E. Górecki, J. Krukowski, M. Sitarz, Komentarz..., s. 430. 
Homilia zajmuje wśród form głoszenia słowa Bożego pierwsze miejsce. Podczas niej wykładane są tajemnice wiary i normy życia chrześcijańskiego. Jej głoszenie ustawodawca reguluje w kan. 767 - „§ 1 . Wśród różnych form przepowiadania szczególne miejsce zajmuje homilia. Stanowi ona część samej liturgii i jest zarezerwowana kapłanowi lub diakonowi. W ciągu roku liturgicznego należy wykładać w niej na podstawie świętych tekstów tajemnice wiary oraz zasady życia chrześcijańskiego. $§ 2$. We wszystkich Mszach św. w niedziele i święta nakazane, odprawianych z udziałem wiernych, homilia jest obowiązkowa i nie wolno jej opuszczać bez poważnej przyczyny. $§ 3$. Gdy jest odpowiednia liczba wiernych, bardzo zaleca się homilię także w Mszach św. odprawianych w ciągu tygodnia, zwłaszcza w okresie adwentu i wielkiego postu, albo z racji jakiegoś święta lub wydarzenia żałobnego. § 4 . Do proboszcza lub rektora kościoła należy czuwać, by te przepisy były wiernie przestrzegane".

Homilia jest zarezerwowana dla kapłana i diakona. „Biskup nie może dyspensować od tej normy", jak wskazuje interpretacja autentyczna PCI z 20 VI 1987 r. $^{31}$.

Nauczanie papieskie wskazuje na doniosłą rolę homilii - „Homilia wymaga największej pilności; trzeba także dbać, by nie była ona za długa, ani też zbyt krótka, aby była zawsze starannie przygotowana, bogata w myśli, dostosowana do słuchających i zastrzeżona duchownym wyświęconym. Powinna być głoszona podczas każdej Eucharystii w niedziele i święta obowiązkowe, a także przy udzielaniu chrztu, w obrzędach pokuty, małżeństwa i pogrzebu. Jest to jedno z dobrodziejstw odnowy liturgicznej"32.

Ustawodawca nakazuje, aby wiernym przekazywać naukę, jaką Urząd Nauczycielski Kościoła głosi o godności i wolności osoby ludzkiej, również o rodzinie i jej zadaniach, o obowiązkach społecznych (kan. $528 \S 1)^{33}$, jak też o układaniu spraw doczesnych zgodnie z porządkiem ustanowionym przez Boga (kan. 768 § 2). Podkreśla też, aby naukę przedkładać „w sposób dostosowany do poziomu słuchaczy, z uwzględnieniem potrzeb czasu" (kan. 769). Obowiązkiem proboszcza jest organizowanie rekolekcji i misji świętych lub innych form przepowiadania dostosowanych do potrzeb parafii (kan. 779).

Jeżeli na terenie parafii znajdują się takie osoby, które „nie mogą dostatecznie korzystać z ogólnej i zwyczajnej opieki duszpasterskiej albo są

${ }^{31}$ P. Majer (red.), Codex Iuris Canonici Kodeks Prawa Kanonicznego. Komentarz, Kraków 2011, s. 593, Dodatek, s. 1324, 20 VI 1987 (AAS 79 [1987], s. 1249). PCI (Pontificia Commissio ad Codicis Canones Authentice Interpretandos).

${ }^{32}$ Catechesi tradendae 48.

33 S. J. Lederhilger, Der Pfarrer..., s. 698. 
jej całkowicie pozbawieni" (kan. $771 \S 1$ ), jak szpitale i zakłady opieki, to proboszcz ma zatroszczyć się, aby i im było głoszone słowo Boże ${ }^{34}$. Należy to czynić także wobec niewierzących, wykorzystując w tym celu spotkania z wiernymi z racji różnych okoliczności (kan. $771 \S 2$ ), w których biorą udział wierzący i niewierzący, np. pogrzeby, śluby, dożynki i in. Zadaniem proboszcza jest również inicjować i koordynować działania ekumeniczne, jeżeli na terenie parafii czy w relacjach interparafialnych znajdują się członkowie innych wyznańn ${ }^{35}$. Rozwój nowych technicznych środków przekazu informacji powinien skłonić proboszcza do otwartości na nie i skorzystania także z tej formy przekazu w głoszeniu słowa Bożego (kan. $772 \S 2$ ). Internet, radio, telewizja nie mogą być pominięte w szukaniu sposobów głoszenia słowa Bożego ${ }^{36}$.

\section{b) Nauczanie katechetyczne}

Ustawodawca nakłada na duszpasterzy obowiązek troski o katechizację. Zgodnie z kan. 773 - „Własnym i poważnym obowiązkiem, zwłaszcza duszpasterzy, jest troska o katechizację ludu chrześcijańskiego, ażeby wiara wiernych przez przyjmowanie nauki i doświadczenie życia chrześcijańskiego stawała się żywa, wyraźna i czynna”. Stąd wynika, że "ta forma nauczania słowa Bożego powinna obejmować dwa wymiary: nauczanie doktryny i doświadczenie życia chrześcijańskiego" ${ }^{\prime 37}$. Proboszcz ma czuwać nad bezbłędnym głoszeniem doktryny, jak również nad tym, aby doświadczenie życia chrześcijańskiego było zgodne w pełni z moralnością chrześcijańską i to zarówno u katechizujących, jak i katechizowanych.

Pod jego kierownictwem mają troszczyć się o katechezę wszyscy należący do wspólnoty parafii (kan. 774 § 1). Obowiązek przekazywania prawd wiary mają przede wszystkim rodzice, ci, którzy zastępują rodziców i rodzice chrzestni (kan. 774 § 2).

Wśród duszpasterzy mających troszczyć się o nauczanie katechezy, ustawodawca wymienia przede wszystkim proboszcza Kan. 776 stanowi, że ,z racji swej funkcji, proboszcz obowiązany jest troszczyć się o nauczanie katechetyczne dorosłych, młodzieży i dzieci”. W tej trosce powinni go wspierać duchowni (wikariusze, diakoni przebywający na praktykach), członkowie instytutów życia konsekrowanego (ojcowie i bracia zakonni,

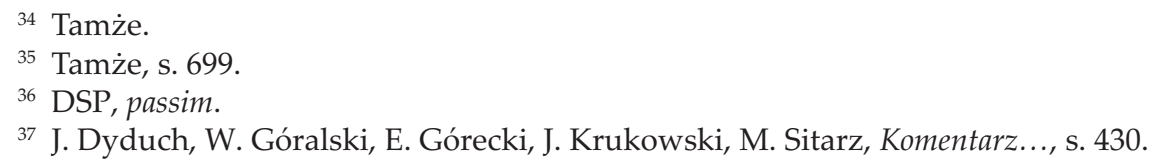


siostry zakonne), jak również katechetki i katecheci świeccy. Proboszcz powinien „popierać i umacniać zadanie rodziców w zakresie katechezy rodzinnej" (kan. 776). Zadaniem proboszcza jest również troska o katechezę młodzieży pozaszkolnej oraz dorosłych, poprzez popieranie różnych grup formacyjnych w duszpasterstwie parafialnym.

Homilia i katecheza stanowią główne formy głoszenia słowa Bożego. Poza nimi jednak jest wiele obszarów życia chrześcijańskiego, które wymagają przepełnienia ich duchem Ewangelii, sfera życia społecznego, gospodarczego, politycznego. Dostrzeżenie potrzeb duchowych poszczególnych grup społecznych i zawodowych (robotnicy, nauczyciele, lekarze, strażacy) i zorganizowanie stosownych form nauczania pozostaje zadaniem proboszcza (kan. 770). Należy tu wymienić rekolekcje, misje parafialne i ewangelizacyjne.

Ustawodawca nakłada na proboszcza obowiązek troski o nauczanie katechetyczne związane z przyjmowaniem sakramentów świętych. Zgodnie z kan. 777 - „Uwzględniając normy wydane przez biskupa diecezjalnego, proboszcz ma w szczególny sposób troszczyć się:

$1^{\circ}$ żeby była prowadzona katecheza przygotowująca do uczestnictwa w sakramentach;

$2^{\circ}$ aby dzieci, przez nauczanie katechetyczne trwające odpowiedni okres czasu, właściwie zostały przygotowane do pierwszego przyjęcia sakramentów pokuty i Najświętszej Eucharystii oraz do sakramentu bierzmowania;

$3^{\circ}$ by dzieci, po przyjęciu pierwszej Komunii świętej, były w dalszym ciągu przez formację katechetyczną szczegółowiej i w sposób bardziej pogłębiony kształtowane;

$4^{\circ}$ ażeby katechizować także upośledzonych fizycznie i umysłowo, na ile pozwala na to ich stan;

$5^{\circ}$ ażeby przez zastosowanie różnych form i poczynań umacniać, oświecać i potęgować wiarę młodzieży i dorosłych".

\section{c) Katolickie wychowanie dzieci i młodzieży}

Ustawodawca nakłada na proboszcza szczególny obowiązek w zakresie katolickiego wychowania dzieci i młodzieży ${ }^{38}$. Mają temu służyć szkoły katolickie (kan. 800-806). Chociaż ustawodawca tę troskę powierza głównie biskupowi, to w praktyce nad organizacją nauczania kateche-

\footnotetext{
${ }^{38}$ J. Dyduch, W. Góralski, E. Górecki, J. Krukowski, M. Sitarz, Komentarz..., s. 430.
} 
tycznego i wychowania katolickiego czuwa proboszcz, na terenie którego parafii taka szkoła znajduje się. W szkołach publicznych proboszcz powinien również zatroszczyć się o katolickie wychowanie dzieci i młodzieży.

\section{Obowiązki w zakresie uświęcania (munus sanctificandi)}

Przepis kan. $528 \S 2$ zawiera w swojej treści zadania proboszcza odnośnie do munus sanctificandi. Wprawdzie nie w wyczerpujący sposób, ale sumarycznie $^{39}$ ustawodawca wskazuje na konkretne obowiązki - „Proboszcz troszczy się o to, ażeby sprawowanie Eucharystii stało się centrum parafialnego zgromadzenia wiernych. Pracuje nad tym, by wierni wzmacniali się przez pobożne uczestniczenie w sakramentach, a zwłaszcza często przystępowali do sakramentów Najświętszej Eucharystii i pokuty. Stara się również o to, by wierni modlili się, także w rodzinach, oraz świadomie i czynnie uczestniczyli w liturgii. Proboszcz, pod władzą biskupa diecezjalnego, winien kierować liturgią w swojej parafii i czuwać nad tym, by nie wkradły się do niej nadużycia".

Zgodnie z nauczaniem Soboru Watykańskiego II w centrum życia wspólnoty parafialnej ma stać Eucharystia ${ }^{40}$. Zadanie uświęcania parafian dokonuje się przede wszystkim przez sprawowanie Eucharystii i troskę o owocne w niej uczestniczenie.

39 S. J. Lederhilger, Der Pfarrer..., s. 699.

${ }^{40} \mathrm{KK} 11$ „Uczestnicząc w Ofierze eucharystycznej, tym źródle i zarazem szczycie całego życia chrześcijańskiego, składają Bogu boską Żertwę ofiarną, a wraz z nią samych siebie, w ten sposób zarówno przez składanie ofiary, jak i przez Komunię święta, wszyscy biorą właściwy sobie udział w czynności liturgicznej, niejednakowo, lecz jedni tak drudzy inaczej. Posileni zaś w świętej Komunii Ciałem Chrystusowym, w konkretny sposób przedstawiają jedność Ludu Bożego, której stosownym znakiem i cudowną przyczyną jest ten Najświętszy Sakrament”; CD 30, 2 „W dokonywaniu dzieł uświęcania niech się proboszczowie zatroszcza, by odprawianie Ofiary eucharystycznej było ośrodkiem i uwieńczeniem całego życia wspólnoty chrześcijańskiej. Tak samo niech dołożą starań, by wierni posilali się duchowym pokarmem przez pobożne i częste przyjmowanie sakramentów oraz przez świadomy i czynny udział w liturgii. Proboszczowie winni także pamiętać, jak ogromnie przyczynia się do wyrobienia życia wewnętrzny sakrament pokuty, toteż niech się chętnie oddają słuchaniu spowiedzi wiernych, zapraszając w tym celu, w razie potrzeby, również innych kapłanów, którzy by władali innymi językami”; KKK 1324 Eucharystia jest „źródłem i zarazem szczytem całego życia chrześcijańskiego" (Sobór Watykański II, konst. Lumen gentium, 11). „Inne zaś sakramenty, tak jak wszystkie kościelne posługi i dzieła apostolstwa, wiążą się ze świętą Eucharystią i do niej zmierzają. W Najświętszej bowiem Eucharystii zawiera się całe duchowe dobro Kościoła, a mianowicie sam Chrystus, nasza Pascha" (Sobór Watykański II, dekret Presbyterorum ordinis, 5). 
Ustawodawca przetransponował tę soborową naukę na język jurydyczny i zawarł w kan. 897. Zgodnie z nim - „Najbardziej czcigodnym sakramentem jest Najświętsza Eucharystia, w której sam Chrystus Pan jest obecny, ofiaruje się oraz jest spożywany i dzięki której Kościół ustawicznie żyje i wzrasta. Ofiara eucharystyczna, pamiątka śmierci i zmartwychwstania Pana, w której uwiecznia się Ofiara Krzyża, jest szczytem i źródłem całego kultu oraz życia chrześcijańskiego; oznacza ona i sprawia jedność Ludu Bożego, przez nią buduje się Ciało Chrystusa. Pozostałe bowiem sakramenty i wszystkie kościelne dzieła apostolatu mają związek z Najświętszą Eucharystią i ku niej są ukierunkowane".

Nie mniejsze znaczenie ma obowiązek troski o częste przyjmowanie Komunii św. nałożony przez ustawodawcę w kan. 898, według którego „Wierni powinni z największym szacunkiem odnosić się do Najświętszej Eucharystii, biorąc czynny udział w sprawowaniu najczcigodniejszej Ofiary, z największą pobożnością i często przyjmując ten sakrament i adorując Go z najwyższą czcią. Duszpasterze wyjaśniając naukę o tym sakramencie powinni starannie pouczać wiernych o tym obowiązku". Troska proboszcza ma dotyczyć udziału wiernych w Eucharystii, częstego przyjmowania Komunii św. i czci dla Najświętszego Sakramentu. Ma to prowadzić do przeżywania jedności doktryny o Eucharystii i pobożności eucharystycznej ${ }^{41}$.

Pobożność eucharystyczna domaga się tego, aby miejsce przechowywania Najświętszego Sakramentu było szczególnie widoczne lub wydzielone, dostępne, ozdobione ${ }^{42}$ i sprzyjające skupieniu. Zgodnie z kan. 938 $\S 2$ - „Tabernakulum, w którym przechowuje się Najświętszą Eucharystię, winno być umieszczone w odznaczającej się, widocznej, stosownie przyozdobionej i odpowiedniej dla modlitwy części kościoła lub kaplicy".

Obowiązkiem proboszcza jest również organizowanie różnych form kultu Eucharystii, takich jak wystawienie Najświętszego Sakramentu. Na mocy kan. $941 \S 1$ „W kościołach lub kaplicach, które mają zezwolenie na przechowywanie Najświętszej Eucharystii, można dokonywać jej wystawienia $\mathrm{w}$ puszce lub monstrancji, $\mathrm{z}$ zachowaniem norm przepisanych w księgach liturgicznych". Ożywieniu kultu eucharystycznego służą procesje eucharystyczne, co jest zalecane zgodnie z kan. $944 \S 1$ "Gdzie, zdaniem biskupa diecezjalnego, jest to możliwe, należy dla publicznego świadectwa czci wobec Najświętszej Eucharystii urządzać; zwłaszcza

${ }^{41}$ P. Majer (red.), Codex..., s. 681.

${ }^{42}$ J. Dyduch, W. Góralski, E. Górecki, J. Krukowski, M. Sitarz, Komentarz..., s. 431. 
w uroczystość Ciała i Krwi Chrystusa, procesję prowadzoną po drogach publicznych".

To doniosłe znaczenie Eucharystii w życiu duchowym chrześcijanina zobowiązuje proboszcza do właściwego jej sprawowania. Sposób sprawowania Eucharystii przez proboszcza ma zachęcać wiernych parafian do częstego, chętnego i aktywnego w niej uczestniczenia ${ }^{43}$.

Aby wierni owocnie uczestniczyli w Eucharystii proboszcz jest zobowiązany do troski o sprawowanie sakramentu pokuty. Ma troszczyć się o ustalenie dogodnych dla wiernych dni i godzin. Ten obowiązek nakłada ustawodawca w kan. $986 \S 2$ - „Każdy, komu na mocy urzędu została zlecona troska duszpasterska, jest obowiązany dbać o to, ażeby wierni jemu powierzeni mogli się wyspowiadać, jeśli w sposób uzasadniony o to prosza, a także by dać im sposobność przystępowania do indywidualnej spowiedzi, w ustalonych i dogodnych dla nich dniach i godzinach".

Zadaniem proboszcza jest również zachęcanie wiernych do modlitwy, szczególnie w rodzinie. Ma też obowiązek popierania i animowania różnych grup modlitewnych w parafii. Zadanie uświęcania jest powierzone obok biskupów również prezbiterom, według przepisu kan. $835 \S$ 2. Zgodnie z nim „Wykonują je również prezbiterzy, którzy będąc także uczestnikami kapłaństwa Chrystusowego, jako jego szafarze pod władzą biskupa, są konsekrowani do sprawowania kultu Bożego i uświęcania ludu". Troska o uświęcanie ludu przez zachęcanie do pogłębiania nauki

${ }^{43}$ Jan Paweł II, Encyklika Ecclesia de Eucharistia, 17 IV 2003, nr 52 „Z tego, co zostało wyżej powiedziane, można zrozumieć, jak wielka odpowiedzialność spoczywa przy sprawowaniu Eucharystii zwłaszcza na kapłanach, którym przysługuje zadanie przewodniczenia jej in persona Christi, zapewniając świadectwo i posługę komunii nie tylko wobec wspólnoty bezpośrednio biorącej w niej udział, lecz także wobec Kościoła powszechnego, który zawsze jest przywoływany przez Eucharystię. [...] Czuję się zatem w obowiązku skierować gorący apel, ażeby podczas sprawowania Ofiary eucharystycznej normy liturgiczne były zachowywane z wielką wiernością. Są one konkretnym wyrazem autentycznej eklezjalności Eucharystii; takie jest ich najgłębsze znaczenie. Liturgia nie jest nigdy prywatną własnością kogokolwiek, ani celebransa, ani wspólnoty, w której jest sprawowana tajemnica. [...] Również w naszych czasach posłuszeństwo normom liturgicznym powinno być na nowo odkryte i docenione jako odbicie i świadectwo Kościoła jednego i powszechnego, uobecnionego w każdej celebracji Eucharystii. Kapłan, który wiernie sprawuje Mszę św. według norm liturgicznych, oraz wspólnota, która się do nich dostosowuje, ukazują w sposób dyskretny, lecz wymowny swą miłość do Kościoła. [...] Nikomu nie można zezwolić na niedocenianie powierzonej nam tajemnicy: jest ona zbyt wielka, ażeby ktoś mógł pozwolić sobie na traktowanie jej wedle własnej oceny, która nie szanowałaby jej świętego charakteru i jej wymiaru powszechnego". 
Kościoła, uczestnictwo w grupach modlitewnych ma prowadzić do bardziej świadomego uczestniczenia w liturgii ${ }^{44}$.

Zadanie uświęcania ludu Bożego wykonuje proboszcz nie tylko w liturgii. Ma to miejsce również podczas sprawowania obrzędów paraliturgicznych ${ }^{45}$, jak modlitwy w domu rodzin podczas np. kolędy, poświęcenia pól i in. Dokonuje się to także poprzez „dzieła pokuty i miłości”, Według kan. $839 \S 1$ „Zadanie uświęcania wypełnia Kościół także przy pomocy innych środków, czy to przez modlitwy, w których prosi Boga o uświęcenie wiernych w prawdzie, czy to przez dzieła pokuty i miłości, które przyczyniają się bardzo do zaszczepienia i umocnienia Królestwa Chrystusa w duszach oraz do zbawienia świata.

Proboszcz wykonuje zadanie uświęcania pod władzą biskupa i w łączności z nim, stąd powinien czuwać, aby ani w liturgii ani w innych formach uświęcania nie dochodziło do nadużyć. „Ordynariusze miejsca powinni troszczyć się, by modlitwy oraz pobożne i święte ćwiczenia ludu chrześcijańskiego w pełni odpowiadały przepisom Kościoła" (kan. 839 § 2).

Zadaniem proboszcza jest czuwać nad tym, aby sakramenty były sprawowane zgodnie z przepisami prawa. Ma to ścisły związek z troską o ważność sprawowanych sakramentów i godziwość ich udzielania. Ma on czuwać, aby nie dochodziło do nadużyć, by zachować należytą powagę i szacunek dla sprawowanych sakramentów ${ }^{46}$.

\section{Obowiązki w zakresie pasterzowania (munus regendi)}

Papież Benedykt XVI podczas audiencji generalnej w dniu 26 maja 2010 r. zdefiniował munus regendi w następujący sposób: „Kościół jest powołany i zobowiązuje się do sprawowania tego typu władzy, która jest

${ }^{44}$ S. J. Lederhilger, Der Pfarrer..., s. 699; KL 14 „Matka Kościół bardzo pragnie, aby wszyscy wierni byli wdrażani do pełnego, świadomego i czynnego udziału w obrzędach liturgicznych [...] Dlatego duszpasterze w całej swej pastoralnej działalności powinni gorliwie dążyć do zapewnienia takiego udziału przez należyte wychowanie wiernych. 19 Niech duszpasterze gorliwie i cierpliwie zabiegają o liturgiczne wychowanie oraz czynny udział wiernych, tak wewnętrzny, jak i zewnętrzny, stosownie do ich wieku, stanu, rodzaju życia i stopnia kultury religijnej. Niech spełniają w ten sposób jeden z głównych obowiązków wiernego szafarza Bożych misteriów, prowadząc swoją owczarnię w tym zakresie nie tylko słowem, lecz także przykładem".

${ }^{45}$ Kongregacja ds. Kultu Bożego i Dyscypliny Sakramentów, Dyrektorium o pobożności ludowej i liturgii. Zasady i wskazania, wyd. pol. Poznań 2003.

${ }^{46}$ J. Dyduch, W. Góralski, E. Górecki, J. Krukowski, M. Sitarz, Komentarz..., s. 431. 
służbą i sprawuje ją nie własnym tytułem, lecz w imię Jezusa Chrystusa, który otrzymał od Ojca wszelką władzę na niebie i na ziemi (por. Mt 28,18). Albowiem to przez pasterzy Kościoła Chrystus pasie swoją owczarnię: to On ją prowadzi, strzeże jej, napomina ją gdyż głęboko ją kocha. Jednakże Pan Jezus, Najwyższy Pasterz naszych dusz, zechciał, aby Kolegium Apostolskie - dzisiaj biskupi - we wspólnocie z Następcą Piotra oraz kapłani - ich najcenniejsi współpracownicy, uczestniczyli w tej Jego misji troski o Lud Boży i wychowywania go w wierze, ukierunkowując, ożywiając i wspierając wspólnotę chrześcijańską lub - jak mówi Sobór - troszcząc się zwłaszcza „o to, by każdy z wiernych został w Duchu Świętym doprowadzony do rozwoju własnego powołania według zasad Ewangelii, do szczerej i czynnej miłości oraz wolności, ku której wyswobodził nas Chrystus" ${ }^{\prime 7}$. Każdy Pasterz jest więc pośrednikiem, przez którego sam Chrystus miłuje ludzi: to przez naszą posługę - drodzy kapłani - i przez nas Pan dociera do dusz, poucza je, strzeże i prowadzi. [...] Choć takie zadanie duszpasterskie ma swe podstawy w Sakramencie, to jednak jego skuteczność zależy od osobistego życia kapłana. Aby być pasterzem według serca Bożego (por. Jer 3.15), niezbędne jest głębokie zakorzenienie w żywej przyjaźni z Chrystusem, nie tylko inteligencji, ale także wolności i woli, jasna świadomość tożsamości otrzymanej w święceniach kapłańskich, bezwarunkowa dyspozycyjność do prowadzenia powierzonej owczarni tam, gdzie chce tego Pan a nie w tym kierunku, który pozornie wydaje się odpowiedniejszy bądź łatwiejszy. [...] Dlatego ten, kto wkracza w święty sakrament kapłaństwa - w ",hierarchię", nie jest autokratą lecz wchodzi w nową więź posłuszeństwa Chrystusowi: jest z Nim związany we wspólnocie z innymi członkami sakramentu, kapłaństwa. [...] Pasterz jest więc tym, kto prowadzi i strzeże owczarni, niekiedy uniemożliwiając jej rozpraszanie. Poza wyraźną i jasną wizją nadprzyrodzoną nie można zrozumieć właściwego kapłanom zadania kierowania. [...] Jeśli celem jest niesienie orędzia Chrystusa i doprowadzenie ludzi do zbawczego spotkanie z Nim, aby mieli życie, zadanie przewodzenia jawi się jako służba przeżywana w całkowitym daniu siebie, by zbudować owczarnię w prawdzie i świętości, często idąc pod prąd i pamiętając o tym, że ten, kto jest największy, ma być jako najmniejszy, a przełożony jako sługa (por. Lumen gentium, 27). [...] Nie lękajcie się więc prowadzenia do Chrystusa każdego z braci, których On wam powierzył, mając pewność, że każde słowo i działanie, jeśli wypływają z posłuszeństwa woli Bożej, przyniosą owoc; umiejcie żyć, doceniając zalety i uznając ograniczenia kultury, w której ży-

\footnotetext{
47 Presbyterorum Ordinis 6.
} 
jemy, z mocną pewnością że głoszenie Ewangelii jest największą służbą jaką można oddać człowiekowi" ${ }^{48}$.

Tak nakreślone zadania pasterzowania wymagają od proboszcza poznania wiernych, uczestniczenia $\mathrm{w}$ ich trudnościach, wspomagania ich, troski o chorych, ubogich, cierpiących, o rodziny. Ustawodawca nakłada te obowiązki w kan. 529 - „§ 1. Pragnąc dobrze wypełnić funkcję pasterza, proboszcz powinien starać się poznać wiernych powierzonych jego pieczy. Winien zatem nawiedzać rodziny, uczestnicząc w troskach wiernych, zwłaszcza niepokojach i smutku, oraz umacniając ich w Panu, jak również - jeśli w czymś nie domagają - roztropnie ich korygując. Gorącą miłością wspiera chorych, zwłaszcza bliskich śmierci, wzmacniając ich troskliwie sakramentami i polecając ich dusze Bogu. Szczególną troską otacza biednych, cierpiących, samotnych, wygnańców oraz przeżywających szczególne trudności. Stara się wreszcie o to, by małżonkowie i rodzice otrzymali pomoc do wypełniania własnych obowiązków oraz popiera wzrost życia chrześcijańskiego w rodzinach. § 2. Proboszcz uznaje i popiera własny udział wiernych świeckich w misji Kościoła, udzielając również poparcia ich stowarzyszeniom o celach religijnych. Współpracuje z własnym biskupem i diecezjalnym prezbiterium, zabiegając także o to, by wierni troszczyli się o parafialną wspólnotę, czuli się członkami zarówno diecezji, jak i Kościoła powszechnego, oraz uczestniczyli w rozwijaniu lub podtrzymywaniu tej wspólnoty".

Poznawanie parafian ma na celu umacnianie ich w formacji duchowej i roztropne korygowanie ewentualnych błędów. To wykracza poza zwyczajną troskę o organizacyjny porządek prowadzenia powierzonego sobie $\operatorname{ludu}^{49}$. Ma on uczestniczyć w troskach, obawach i trudnościach rodzin. Ma wzmacniać powierzonych swojej trosce duszpasterskiej wiernych poprzez duchowa, a także, gdy sytuacja tego wymaga - materialną pomoc oraz dodawać odwagi ${ }^{50}$.

Z miłością pasterską ma odwiedzać chorych, udzielać im sakramentu pokuty, namaszczenia chorych (kan. 998, 1001), Komunii św. (kan. 919 § 3), umierającym udzielać Wiatyku i modlić się za nich. Ze szczególną troską powinien traktować biednych, prześladowanych, samotnych i uchodźców. Nie powinien unikać trudnych sytuacji pasterskiej posługi, gdy zachodzi potrzeba, udzielić upomnienia błądzącym, by sprowadzić

\footnotetext{
48 Tłum. S. Tasiemski, KAI.

49 S. J. Lederhilger, Der Pfarrer..., s. 699.

${ }^{50}$ P. Majer (red.), Codex..., s. 456.
} 
ich na właściwą drogę. Mądre upomnienie, cierpliwe wskazywanie właściwych dróg życia, to ważne elementy posługi pasterskiej.

Zadaniem pasterza jest wspierać rodziców w chrześcijańskim wychowaniu dzieci. Nie powinien przy tym czynić tego jako jedynie sam wszystko wiedzący, ale z należytą pokorą winien dostrzegać charyzmaty wiernych. Powinien je rozpoznawać i wspierać stowarzyszenia wiernych.

Do zadań pasterza należy troska o jedność parafii. Ma to czynić jednak tak, aby było widać, że on wypełnia tę posługę w jedności z biskupem, z prezbiterium diecezji. Parafianami ma tak kierować, aby mieli oni świadomość, że przedmiotem ich troski ma być nie tylko wspólnota parafialna, ale również communio całej diecezji i całego Kościoła ${ }^{51}$.

\section{a) Szczególne zadania i uprawnienia proboszcza}

Z troska pasterską proboszcza bardzo ściśle związane są te obowiązki i działania, które są specjalnie powierzone proboszczowi ${ }^{52}$, chociaż mogą je spełniać i inni kapłani. Zgodnie z kan. 530 - „Do funkcji specjalnie powierzonych proboszczowi należą następujące:

$1^{\circ}$ udzielanie chrztu;

$2^{\circ}$ udzielanie sakramentu bierzmowania osobom znajdującym się w niebezpieczeństwie śmierci, według przepisu kan. 883, n. 3;

$3^{\circ}$ udzielanie Wiatyku i namaszczenia chorych, z zachowaniem wszakże przepisu kan. 1003, §§ 2 i 3, a także udzielanie apostolskiego błogosławieństwa;

$4^{\circ}$ asystowanie przy zawieraniu małżeństw i błogosławieniu małżeństw;

$5^{\circ}$ odprawianie pogrzebów;

$6^{\circ}$ święcenie źródła chrzcielnego w okresie wielkanocnym, prowadzenie procesji poza kościołem oraz dokonywanie uroczystych poświęceń poza kościołem;

$7^{\circ}$ bardziej uroczyste sprawowanie Eucharystii w niedziele i święta".

W CIC 1917 te funkcje były "zastrzeżone wyłącznie proboszczowi” (can. 462 Functiones parocho reservatae sunt, nisi aliud iure caveatur) ze względów ekonomicznych, beneficjalnych. Motyw tego przepisu w kan. 530 jest natury porządkowej w sprawowaniu posługi duszpasterskiej w parafii.

${ }^{51}$ S. J. Lederhilger, Der Pfarrer..., s. 700; J. Dyduch, W. Góralski, E. Górecki, J. Krukowski, M. Sitarz, Komentarz..., s. 433.

52 S. J. Lederhilger, Der Pfarrer..., s. 700. 
Wymienione w kanonie funkcje mają być wykonywane pod nadzorem i odpowiedzialnością proboszcza, chociaż mogą je spełniać także inni kapłani, którzy są do tego upoważnieni, a nie tylko osobiście przez probosz$\mathrm{Cza}^{53}$.

\section{Chrzest i bierzmowanie}

Do proboszcza, jako zwyczajnego szafarza, należy udzielanie chrztu na terenie jego parafii (kan. 862). Jeżeli osoba ukończyła czternasty rok życia i ma przyjąć chrzest, proboszcz powinien powiadomić biskupa diecezjalnego, gdyż być może biskup będzie chciał sam udzielić chrztu (kan. 863). Obowiązkiem proboszcza jest przygotować rodziców do chrztu ich dziecka (kan. 867 § 1). Ma to uczynić poprzez specjalną katechezę chrzcielną. Jego obowiązkiem jest zatroszczyć się, aby rodzice wybrali chrześcijańskie imię dla swojego dziecka (kan. 855). W wypadku chrztu osoby dorosłej, zadaniem proboszcza jest przeprowadzenie katechezy katechumenalnej, ma też prawo udzielania sakramentu bierzmowania, jeżeli udziela chrztu na mocy urzędu lub zlecenia biskupa diecezjalnego (kan. 883 § 2). Władzę do udzielania sakramentu bierzmowania ma proboszcz względem osób znajdujących się $\mathrm{w}$ niebezpieczeństwie śmierci, taką samą władzę ma także każdy prezbiter (kan. 883 §3).

\section{Błogosławienie małżeństw}

Proboszcz, na mocy swojego urzędu, w granicach własnego terytorium, ma władzę do asystowania przy zawieraniu małżeństw (kan. 1108, 1109) i udzielania błogosławieństwa zaślubionym (kan. 530, $4^{\circ}$ ). Może delegować innego kapłana lub diakona (kan. 1108 § 1). Może mieć ona charakter ogólnego upoważnienia (kan. 1111 § 1). Musi być przekazana określonym osobom w sposób wyraźny. Delegacja specjalna jest wydawana w stosunku do określonego małżeństwa, natomiast delegacja ogólna ma być wydana na piśmie $(1111 \S 2)^{54}$.

Funkcje wymienione $\mathrm{w}$ kanonie mogą być spełniane także $\mathrm{w}$ innych kościołach, które znajdują się na terenie parafii - najczęściej są to kościoły

${ }^{53}$ P. Majer (red.), Codex..., s. 457; Kongregacja ds. Duchowieństwa, Instrukcja Kapłan, pasterz i przewodnik wspólnoty parafialnej nr 22 „Nie są to funkcje przysługujące wyłącznie proboszczowi tak, jakby były jego ekskluzywnym prawem; są mu powierzone w specjalny sposób z racji jego szczególnej odpowiedzialności; w miarę możności winien je przeto pełnić osobiście, albo przynajmniej czuwać nad ich wykonaniem".

${ }^{54}$ S. J. Lederhilger, Der Pfarrer..., s. 701. 
rektoralne lub związane z domem wspólnoty zakonnej lub stowarzyszenia życia wspólnego. Wymagana jest wówczas zgoda proboszcza lub jego delegacja. Kanon 558 stanowi, że "Zachowując przepis kan. 262, rektor w powierzonym sobie kościele nie może sprawować czynności parafialnych, o których w kan. 530, nn. 1-6, bez zgody, a w razie potrzeby także delegacji proboszcza". Relacje pomiędzy proboszczem i rektorem kościoła odnośnie do sprawowania wymienionych czynności liturgicznych powinny być układane w oparciu o prawo powszechne i partykularne, aby uniknąć niejasności w określaniu kompetencji.

\section{Pogrzeby}

Nabożeństwa pogrzebowe z reguły powinny być odprawiane w kościele własnym parafii wiernego zmarłego. Może to być też inny kościół, wybrany przez każdego wiernego, jednak za zgodą rektora tego kościoła i zgodą własnego proboszcza ${ }^{55}$. Zgodnie z kan. 1177 - „§1. Nabożeństwo pogrzebowe za każdego wiernego winno być z reguły odprawione w jego własnym kościele parafialnym,

$\S 2$. Każdy jednak wierny albo ci, do których należy troska o pogrzeb zmarłego, mogą wybrać inny kościół na pogrzeb, za zgodą tego, kto nim zarządza, i po zawiadomieniu własnego proboszcza.

§3. Jeśli śmierć nastąpiła poza własną parafią i nie przeniesiono do niej zwłok ani nie został zgodnie z prawem wybrany inny kościół pogrzebu, nabożeństwo należy odprawić w kościele parafii, gdzie śmierć nastąpiła, chyba że prawo partykularne wyznacza inny kościół".

\section{Udzielanie dyspens}

Do związanych z urzędem proboszcza pełnomocnictw do dyspensowania i stałych uprawnień należy upoważnienie, pod określonymi nadzwyczajnymi warunkami, do dyspensowania nie tylko od zachowania kanonicznej formy zawarcia małżeństwa, lecz także od wszystkich publicznych i tajnych przeszkód małżeńskich prawa kościelnego, z wyjątkiem przeszkody święceń lub też publicznego wiecznego ślubu w instytucie zakonnym prawa papieskiego (kan. 1079 § 2, 1080 § 1). O tak udzielonej dyspensie ma obowiązek powiadomić natychmiast ordynariusza miejsca (kan. 1081). Takie samo uprawnienie ma proboszcz odnośnie do uważnienia małżeństwa, gdy istnieje niebezpieczeństwo wielkiej szkody, która

\footnotetext{
${ }^{55}$ J. Dyduch, W. Góralski, E. Górecki, J. Krukowski, M. Sitarz, Komentarz..., s. 435.
} 
wynikłaby ze zwłoki i nie ma czasu na zwrócenie się do Stolicy Apostolskiej czy ordynariusza miejsca (kan. 1080 § 2). Proboszcz na mocy posiadanego urzędu ma władzę spowiadania (kan. 968 § 1).

Może powierzonych sobie wiernych jak też obcych dyspensować od ślubów prywatnych (kan. 1192 § 1) lub zamienić je na równe lub większe dobro (kan. $11961^{\circ}$, 1197).

W poszczególnych wypadkach (casus urgens), (zasada ogólna stanowi, że proboszczowie lub inni kapłani i diakoni nie mają władzy dyspensowania, kan. 89) ${ }^{56}$ może ze słusznej przyczyny, według przepisów diecezjalnych, dyspensować od obowiązku zachowania dnia świątecznego czy dnia pokutnego lub zamienić je na inne pobożne dzieła, stosownie do przepisu kan. 1245 - „Przy zachowaniu prawa biskupów diecezjalnych, o których w kan. 87, proboszcz może, dla słusznej przyczyny i według przepisów biskupa diecezjalnego, udzielić w poszczególnych wypadkach dyspensy od obowiązku zachowania dnia świątecznego lub dnia pokuty, albo dokonać zamiany tego obowiązku na inne uczynki pobożne; to samo może uczynić również przełożony kleryckiego instytutu zakonnego lub stowarzyszenia życia apostolskiego na prawie papieskim, w odniesieniu do swoich podwładnych oraz innych osób przebywających na stałe $\mathrm{w}$ domu". Takie kompetencje nie przysługują osobom świeckim ${ }^{57}$. Udzielający dyspensy musi mieć na uwadze to, że będzie to służyło dobru duchowemu tych, którym dyspensa jest udzielana ${ }^{58}$. Adresatem dyspensy może być sam jej autor ${ }^{59}$.

\section{b) Szczególne obowiązki związane z urzędem proboszcza}

Do zakresu pasterskich zadań proboszcza należy reprezentowanie parafii jako osoby prawnej na zewnątrz i zarząd majątkiem kościelnym. Normę tą ustawodawca zawarł w kan. 532 - „W załatwianiu wszystkich czynności prawnych proboszcz występuje w imieniu parafii, zgodnie

56 KPK 89 „Proboszcz i inni prezbiterzy lub diakoni nie mogą dyspensować od ustawodawstwa powszechnego i partykularnego, chyba że taka władza byłaby im wyraźnie udzielona". Proboszczowi na mocy urzędu nie przysługuje władza dyspensowania, J. Krukowski, R. Sobański, Komentarz..., s. 155.

${ }^{57}$ J. Krukowski, R. Sobański, Komentarz..., s. 156; Comm 19, 1987, 79. 89-90.

58 J. Krukowski, R. Sobański, Komentarz..., s. 154.

59 KPK kan. 91 „Kto posiada władzę dyspensowania, ma prawo wykonywać ją będąc także poza terytorium w stosunku do podwładnych, chociażby nieobecnych na terytorium, a także jeśli czegoś innego wyraźnie nie postanowiono, w stosunku do podróżnych, przebywających aktualnie na terytorium, a również względem samego siebie". 
z przepisami prawa. Ma również troszczyć się o to, by dobra parafii były administrowane według norm kan. 1281-1288".

Proboszcz jest legalnym reprezentantem parafii odnośnie do spraw, które dotyczą czynności prawnych zmieniających sytuację majątkową parafii. Reprezentuje on parafię zarówno w prawnym porządku kościelnym, jak i państwowym ${ }^{60}$, chociaż „prawo kanoniczne reguluje kompetencje proboszcza tylko w zakresie kościelnym" ${ }^{\prime 61}$. Takie same uprawnienia w tym względzie ma administrator parafii.

Funkcja reprezentowania parafii podczas dokonywania czynności prawnych nie może być rozumiana arbitralnie. Proboszcz przed podjęciem decyzji, tam, gdzie prawo tego wymaga, powinien wysłuchać opinii organów doradczych, rady do spraw ekonomicznych lub rady do spraw duszpasterskich. Organy te nie mogą go jednak pozbawić prawa reprezentowania parafii ${ }^{62}$. Proboszcza w podejmowaniu decyzji obowiązuje zasada legalności, $\mathrm{zn}$. w swoich działaniach ma stosować się do przepisów prawa, zarówno kanonicznego jak i państwowego.

\section{Obowiązek rezydencji}

Proboszcz ma obowiązek rezydencji, $\mathrm{z}$ reguły $\mathrm{w}$ domu parafialnym, plebanii w pobliżu kościoła parafialnego. Zgodnie z kan. 533 „§ 1. Proboszcz ma obowiązek rezydować w domu parafialnym w pobliżu kościoła. W szczególnych wszakże przypadkach, mając na uwadze słuszną przyczynę, ordynariusz miejsca może zezwolić, aby gdzie indziej zamieszkał, zwłaszcza w domu wspólnym dla wielu kapłanów, jeśli zostanie zabezpieczone właściwe i odpowiednie wykonanie parafialnych zadań. § 2. Jeśli czego innego nie domaga się poważny powód, wolno proboszczowi każdego roku opuścić parafię z racji wakacji najdłużej przez miesiąc, czy to ciągły, czy to z przerwami. Nie wlicza się do niego rekolekcji, odbywanych jeden raz w roku. Gdy proboszcz opuszcza parafię na ponad tydzień, obowiązany jest powiadomić o tym ordynariusza miejsca. §3. Biskup diecezjalny powinien wydać przepisy, aby pod nieobecność proboszcza zabezpieczyć pieczę duszpasterską w parafii przez kapłana wyposażonego w potrzebne uprawnienia".

${ }^{60}$ Ustawa z dnia 17 maja 1989 r. o stosunku Państwa do Kościoła katolickiego w RP, tekst jednolity, Dz. U. z 2013 r. poz. 1169 (art. 7 ust 3 pkt 5 oraz art. 8 ust. 2 pkt 3); P. Majer (red.), Codex..., s. 459.

${ }^{61}$ J. Dyduch, W. Góralski, E. Górecki, J. Krukowski, M. Sitarz, Komentarz..., s. 437.

${ }^{62}$ Tamże. 
Obowiązek rezydencji nie ma charakteru absolutnego. Ordynariusz, w poszczególnych wypadkach, ze słusznej przyczyny, może zezwolić na zamieszkanie proboszcza $w$ innym miejscu. $Z$ zasady jednak plebania powinna być urzędowym miejscem zamieszkania i siedzibą proboszcza jako miejsce jego przebywania i sprawowania duszpasterskiego urzędu. Tam też powinna być usytuowana kancelaria parafialna i archiwum parafii.

Obowiązek rezydencji zawiera obok aspektu miejsca również wymiar czasowy. Przebywanie w plebanii zapewnia proboszczowi sprawne i relatywnie szybkie zarządzanie parafią oraz załatwianie spraw interesantów, którzy z łatwością rozpoznają plebanię jako miejsce przebywania proboszcza i możliwość spotkania go właśnie w tym miejscu.

Ustawodawca uregulował określonymi przepisami także sytuacje nieobecności proboszcza w parafii ${ }^{63}$. Zgodnie z prawem może „każdego roku opuścić parafię z racji wakacji najdłużej przez miesiąc, czy to ciągły czy z przerwami. Nie wlicza się do niego rekolekcji, odbywanych jeden raz w roku" (kan. $533 \S 2$ ). W sytuacji choroby, kuracji czy innej sytuacji, proboszcz ma powiadomić biskupa, do którego należy ustanowienie na czas dłuższej nieobecności proboszcza administratora lub czasowego zastępcy (kan. 539). W parafii, gdzie jest jeden lub więcej wikariuszy tymczasowe kierowanie parafią przejmuje wikariusz parafialny, gdy jest ich kilku, najstarszy nominacją (kan. 541 § 1-2). Poważne naruszenie obowiązku rezydencji jest zagrożone karą. Nie jest wykluczone nawet pozbawienie urzędu, po uprzednim upomnieniu (kan. 1341). Kanon 1396 stanowi, że „Kto poważnie narusza obowiązek rezydencji, do której jest obowiązany z racji urzędu kościelnego, winien być ukarany sprawiedliwą kara, nie wyłączając, po upomnieniu, pozbawienia urzędu".

\section{Applicatio pro populo}

Proboszcz, po zgodnym z prawem objęciu parafii, jest zobowiązany „odprawiać Mszę św. za powierzony sobie lud”. Zgodnie z kan. 534 „§ 1. Po objęciu parafii proboszcz obowiązany jest odprawiać Mszę św. za powierzony sobie lud: we wszystkie niedziele i święta nakazane we własnej diecezji. Jeżeli w jakimś dniu nie może ich odprawić wskutek uznanej przez prawo przeszkody, winien tego dokonać w te same dni przez kogo innego albo $\mathrm{w}$ innym dniu osobiście. $\S 2$. Proboszcz pasterzujący $\mathrm{w}$ kilku parafiach obowiązany jest $\mathrm{w}$ dni wymienione $\mathrm{w} \S 1$, odprawić tylko jedną Mszę św. za cały powierzony sobie lud. $§ 3$. Proboszcz, który nie uczynił

${ }^{63}$ P. Majer (red.), Codex..., s. 459. 
zadość obowiązkowi zgodnie z postanowieniem $\S \S 1$ i 2, powinien jak najszybciej odprawić tyle Mszy św. za wiernych, ile opuścił". Ma to czynić we wszystkie niedziele i święta nakazane. W sytuacji przeszkody, np. choroby, może poprosić o spełnienie tego jego obowiązku innego kapłana lub zadośćuczynić temu obowiązkowi w inny dzień tygodnia ${ }^{64}$. Jeżeli proboszcz ma pod opieką duszpasterską kilka parafii, to zobowiązany jest odprawić za lud tylko jedną Mszę św. W sytuacji zaniedbania tego obowiązku powinien odprawić tyle Mszy św. ile opuścił i może to uczynić poza parafią ${ }^{65}$.

\section{Prowadzenie kancelarii parafialnej}

Proboszcz jest zobowiązany do prowadzenia ksiąg parafialnych, archiwum parafii oraz ma dbać o właściwe przechowywanie i używanie pieczęci parafii. Zgodnie z kan. 535 - „§ 1. W każdej parafii należy prowadzić księgi parafialne, a mianowicie ochrzczonych, małżeństw, zmarłych oraz inne, zgodnie z przepisami Konferencji Episkopatu lub biskupa diecezjalnego. Proboszcz ma czuwać nad tym, by księgi były właściwie spisywane i przechowywane. $\S 2$. W księdze ochrzczonych należy odnotować bierzmowanie, jak również to, co ma związek ze stanem kanonicznym wiernych $\mathrm{z}$ racji małżeństwa, $\mathrm{z}$ zachowaniem wszakże przepisu kan. 1133, z racji adopcji, jak również przyjęcia święceń wyższych, profesji wieczystej złożonej $\mathrm{w}$ instytucie zakonnym oraz zmiany obrządku; adnotacje muszą być zawsze uwidocznione w metryce chrztu. §3. Każda parafia powinna mieć własną pieczęć. Wydawane zaświadczenia kanonicznego stanu wiernych oraz wszystkie akty, które mogą posiadać znaczenie prawne, mają być podpisane przez proboszcza lub jego delegata i opatrzone pieczęcią parafialną. § 4. Każda parafia winna mieć własny depozyt dokumentów czyli archiwum, w którym należy przechowywać księgi parafialne, łącznie z listami biskupów oraz innymi dokumentami, których zachowanie jest konieczne lub pożyteczne. Biskup diecezjalny lub jego delegat powinien, z okazji wizytacji lub w innym czasie, przejrzeć je wszystkie, a proboszcz ma czuwać nad tym, by nic z nich nie dostało się do obcych rąk. §5. Należy pilnie przechowywać także stare księgi parafialne, zgodnie z wymogami prawa partykularnego". Do ksiagg parafialnych zalicza się księgę chrztów, zaślubionych i zmarłych. Konferencje biskupów

\footnotetext{
64 Tamże, s. 460.

65 S. J. Lederhilger, Der Pfarrer..., s. 703.
} 
i prawo partykularne może wprowadzać także inne rodzaje ksiąg ${ }^{66}$. Prowadzenie tych ksiagg może proboszcz zlecić innym osobom, jednak do jego obowiązków należy czuwanie nad ich stanem.

W księdze chrztów ma być obligatoryjnie odnotowany fakt przyjęcia bierzmowania. Poza tym należy zamieścić adnotacje o zawartym małżeństwie, poza zawartymi tajnie, o których adnotacja winna znaleźć się w odrębnej księdze, przechowywanej w archiwum (kan. 1133), adopcji (kan. 877 § 3), przyjęciu święceń diakonatu, kapłaństwa, złożenia ślubów w instytucie zakonnym i zmiana obrządku. Te adnotacje należy zamieścić na urzędowym świadectwie chrztu ${ }^{67}$.

W księdze małżeństw należy zapisać wszystkie małżeństwa zawarte w parafii, włącznie z adnotacjami o dyspensach. Obowiązkiem proboszcza jest wysłać do parafii strony zawierającej małżeństwo ne tẹmere. Księga bierzmowanych, księga zmarłych i in. powinny znajdować się we właściwym stanie, aby można było wykazać fakt przyjęcia bierzmowania, datę śmierci i pogrzebu osoby zmarłej, pogrzebanej na parafialnym cmentarzu.

Pozostałe księgi to księga stypendiów mszalnych. Według kan. 958 „§1. Proboszcz oraz rektor kościoła lub innego pobożnego miejsca, w których zwykło się przyjmować stypendia mszalne, powinni posiadać specjalną książkę, w której dokładnie mają zapisywać liczbę Mszy św. przyjętych do odprawienia, intencje, jak również złożoną ofiarę i odprawienie. $\S 2$. Ordynariusz jest obowiązany każdego roku sprawdzać osobiście lub przez innych te księgi". Księga fundi instructi, która stanowi spis majątku ruchomego i nieruchomego parafii (kan. 1283 § 2-3). Jest to również księga ze spisem dóbr kultury. We właściwy sposób powinna być prowadzona księga zapowiedzi przedślubnych, księga ogłoszeń parafialnych.

Do aktów władzy proboszcza należy podpisywanie i wydawanie dokumentów kościelnych, które dla ważności mają być zaopatrzone w pieczęć parafialną ${ }^{68} \mathrm{i}$ w ten sposób stają się publicznymi kościelnymi dokumentami (kan. 1540 § 1). Obowiązkiem proboszcza jest przechowywanie pieczęci i ochrona, aby nie została wykorzystana niezgodnie z prawem.

Innym obowiązkiem proboszcza jest urządzenie i prowadzenie archiwum parafii, w którym przechowywane są księgi parafialne, listy biskupa diecezjalnego i konferencji biskupów ${ }^{69}$, pisma urzędowe i inne dokumen-

${ }^{66}$ P. Majer (red.), Codex..., s. 461.

67 S. J. Lederhilger, Der Pfarrer..., s. 704.

${ }^{68}$ P. Majer (red.), Codex..., s. 461; J. Dyduch, W. Góralski, E. Górecki, J. Krukowski, M. Sitarz, Komentarz..., s. 443.

${ }^{69}$ J. Dyduch, W. Góralski, E. Górecki, J. Krukowski, M. Sitarz, Komentarz..., s. 443. 
ty (kan. 1208, $1284 \S 2,9^{\circ}$ ), aby nie dostały się w niepowołane ręce ${ }^{70}$. Duplikaty wymaganych ksiąg proboszcz jest zobowiązany przekazać do kurii biskupiej.

Słowa kluczowe: proboszcz, urząd, nauczanie, uświęcanie, pasterzowanie

\section{Bibliografia}

Baron A., Pietras H., Dokumenty Soborów Powszechnych, t. I, Wydawnictwo WAM, Kraków 2002.

Baron A., Pietras H., Dokumenty Soborów Powszechnych, t. II, Wydawnictwo WAM, Kraków 2004.

Dyduch J., Góralski W., Górecki E., Krukowski J., Sitarz M., Komentarz do Kodeksu Prawa Kanonicznego, Księga II Lud Boży, t. II, Poznań 2005.

Haering S., Rees W., Schmitz H., Handbuch des katholischen Kirchenrechts, wyd. 3, Verlag Friedrich Pustet, Regensburg 2015.

Jan Paweł II, Encyklika Ecclesia de Eucharistia, 17 IV 2003.

Jurewicz O., Stownik grecko-polski, t. I-II, Warszawa 2000.

Kongregacja ds. Kultu Bożego i Dyscypliny Sakramentów, Dyrektorium o pobożności ludowej i liturgii. Zasady i wskazania, wyd. pol. Poznań 2003.

Krukowski J., Sobański R., Komentarz do Kodeksu Prawa Kanonicznego, Księga I Normy ogólne, t. I, Poznań 2003.

Majer P. (red.), Codex Iuris Canonici Kodeks Prawa Kanonicznego. Komentarz, Kraków 2011.

Węclewski Z., Słownik grecko-polski, Warszawa 1929.

LG - Lumen Gentium

CD - Christus Dominus

\section{SPECIFIC CANONIC DUTIES OF A PARISH PRIEST PERTAINING TO TEACHING, SANCTIFYING AND PASTORAL CARE}

\section{S u m m a r y}

Parish priest's canonical duties pertaining to teaching, sanctifying and pastoral care are defined by public and subordinate law. A parish as a community of the faithful is a legal person with a parish priest as its head. He is the parish's own shepherd. He serves under the jurisdiction of the Diocesan Bishop. Diocesan Bishop freely nominates a priest to the vacant office of

\footnotetext{
${ }^{70}$ S. J. Lederhilger, Der Pfarrer..., s. 704.
} 
a parish priest. Parish priest's canonical duties pertaining to teaching mainly include preaching the Word of God, those pertaining to sanctifying include conducting the Mass and giving out Sacraments, and those pertaining to pastoral care - leading the community of the faithful that he is responsible for, learning their needs and, if necessary, rebuking them. It is the parish priest in particular who is tasked with Christening, taking care of the Viaticum, sanctifying the sacred water, funerals and dispensations. Connected to the office of a parish priest are the following duties: representing the parish outside, duty of residence, applicatio pro populo, taking care of the parish office.

Key words: Parish priest, office, teaching, sanctifying, pastoral care

\section{КОНКРЕТНЫЕ КАНОНИЧЕСКИЕ ОБЯЗАННОСТИ НАСТОЯТЕЛЯ ОТНОСИТЕЯЬНО УЧЕНИЯ, ОСВЕЩЕНИЯ И ПАСТЫРСТВА}

\section{P е 3 ю м е}

Конкретные канонические обязанности настоятеля в сфере учения, освещения и пастырства определены в общем и партикулярном праве. Приход как общество верных является юридическим дицом, на котором главенствует настоятель. Является он собственным пастырем прихода. Он выполняет свое служение под властью епископа. Епископ добровольно назначает священника на вакантную должность настоятеля. Канонические обязанности настоятеля относительно учения, это в основном разглашать слово Божие, относительно освещения, это совершать богослужение (месса) и христианские таинства, относительно пастырства, это управление сообществом порученных ему верных, узнавание их потребности, необходимости предупреждения ситуаций. В частности, настоятелю доверено совершать крещения, причастие, освещение воды для крещения, похороны, освобождение. Обязанности связаны с управлением настоятелем это: представительство прихода для внешней среды, обязанность резидентства, applicatio pro populo, ведения прихода.

Ключевые слова: настоятель, орган, учение, освещение, пастырство 